\title{
Slovene without a Passport: Ljubljana, Theory, Utopia
}

\author{
Ben Agger
}

All writing that passes for theory is autobiography. Or perhaps it is fiction. I am not the first to notice that writing creates the self. But it works both ways: the world we write is informed by the self we have become. And writing constructs the world. As soon as one throws over positivism, which positions the literary self outside of time and place in pursuit of laws of nature and social nature (a prospect disqualified by Einstein in 1905 and by Derrida later), one recognizes that writing is heavily implicated in the world. This is a way of saying that Ljubljana is 'my' Ljubljana and that Ljubljana is a version of the self I am. But the self I am owes a great deal to the Ljubljana I visited in the late 1960s and 1970s — a veritable intellectual and social utopia, or so it seemed to me. As President John Kennedy proclaimed "I am a Berliner" in a stirring speech in 1963, so I am a citizen of Slovenia. They have forgotten to send me my passport-undoubtedly a bureaucratic oversight!

This is a way to understand the story I tell of the impact of Ljubljana and Slovenia on the self I am, especially the literary self I am. Literary self is vague; it is better to say that I 'am' my vita, that which I have published. I am more, and also, perhaps, less. This depends on whether we agree with Hegel that all work (here, writing) involves loss of the object, an inevitable alienation. Or whether we side with early Marx, he of the 1843-44 manuscripts, when he says that self-objectification need not lead to alienation-the very promise of his utopia.

This is not an idle reference. My Ljubljana has everything to do with my reading of the early Marx. Tito, workers' councils, the Praxis Group are manifestations of the young Marx, who defined alienation and tried to redeem it through a society of praxis - a Greek word for self-creative work that blurring with play (as appreciated by the Freudian Marxism of Marcuse who also probably a Slovenian without a passport).

I am certain that Ljubljana does not mean to be appreciated this way, through the hazy and distant prism of my well-thumbed copies of Marx's early writings and Marcuse's Eros and Civilization. I was also reading Slovenia and the rest of western and eastern Europe through the prism of Sartre's and Merleau-Ponty's existentialism, to which I was introduced by John O'Neill, an Irish Marxist and phenomenologist at York University in Toronto. I was already an ex-pat, a Vietnam-era refuge of the United States living in the cosmopolitan city of Toronto. It was from Toronto that I embarked to Europe as a student, having lived there for a year as a young teenager (when my father, a leftist political scientist, took his sabbatical and did research on community power structures in Czechoslovakia, Poland and the former Yugoslavia). I was always/already a European without a passport by the time I finished college and graduate school in Toronto.

And so my Ljubljana was inserted into this emerging mosaic of intellectual and personal identity. I was reading furiously in Marx, both early and later, German idealism, phenomenology, existentialism, Lukacs, and especially the Frankfurt School. Later, we named our identities_critical theory was my main name, although I could have taken other names such as existential-phenomenology. Later, many of us gave ourselves the additional name of cultural studies. But, for me, cultural studies was made possible through my reading of Horkheimer and Adorno's Dialectic of Enlightenment, in which they identify positivism, a fact fetishism that freezes the present into our supposed 'fate,' a notion consistent with Nietzsche's amor fati, the love of fate. In the later sections of Dialectic, Horkheimer and Adorno initiate cultural studies where they denounce popular culture as "mass deception," a thread taken up by Marcuse in his 1964 book One-Dimensional Man, which I was reading as a first-year college student in Toronto. 
Then there were the French, who participated in the May Movement of 1968 and later questioned what it means to write and read texts such as science and Stalinism that pretend not be stories, even nightmares. Sartre, Derrida and Foucault were writing parallel to the German critical theorists, similar and yet different. Foucault's Discipline and Punish could have been titled One-Dimensional Man, and Derrida's theme of difference is nearly identical to Adorno's concept of non-identity developed in his pessimistic book Negative Dialectics-pessimistic because in it he gives up the notion of a progressive agency through which the world can be changed, deriving directly from the eleventh thesis on Feuerbach: the point of intellectual work is not only to understand the world but to change it. The New Left, both in America and Europe, insisted, through Husserl, early Marx, feminism, praxis philosophy, that collective change is prefigured by changes and choices people make in everyday life. Such as my choice to go to Canada and then study in Europe while escaping Anglo-American positivism.

In late spring and summer of 1968 I was first in Prague, leaving just four days before the Soviet tanks ended the upsurge of humanist Marxism in Czechoslovakia. I left for Ljubljana, which had become a second summer home for me and my family. I was sitting around a streetside Ljubljana café drinking turska kava and puzzling my way through the headlines of Delo as I learned that the Prague Spring had turned autumnal. This left Titoism as the only global embodiment of the early Marx, he of praxis and autogestion.

This traveling and studying (I heard lectures from Petrovic or Stojanovic of the Praxis group at a university building on the former Titova) constructed the 'me' who would, a decade later, begin to write his own works, albeit haltingly. Finding one's voice is difficult in the noisy room of the academy, especially when the temptation posed by mimesis is nearly irresistible. I now had numerous intellectual heroes, French, German, British and Yugoslav, and they all dwarfed my own sensibility. Slowly, slowly, I began to emerge from their shadow and find my own voice. In retrospect, it is clear that my time in Ljubljana and Yugoslavia was formative for me.

What did I learn from these experiences? It is nearly impossible to separate the personal and intellectual. I was young when I first set foot on the tarmac in Dubrovnik, having flown from Luton, England. I was 13. My father had spent time in Yugoslavia in a United Nations relief force toward the end of WWII, and he was fascinated by this Adriatic country that he found. He was also forming plans to do comparative political science, comparing civil society (as we now call it) in both capitalist and state-socialist nations. Yugoslavia was a fascinating exception.

The whole year I spent headquartered in England and Amsterdam, including eastern European and Soviet travel, was a revelation. Although I lived in an American college town, Europe soon began to flow through my veins. Years later, when multiculturalists in the U.S. mounted a critique of 'Eurocentrism,' I secretly knew that I was guilty as charged! European thinkers asked the right questions: what can I know? What can I hope for? What ought I to do? Kant's questions frame the Enlightenment, and opened what Habermas calls the project of modernity. I'm not in favor of abandoning that project even though, as the other Frankfurters point out, enlightenment tends to become domination, even a holocaust, when positivist method sucks all mystery (Adorno's non-identity, Derrida's difference) out of objects, including other people.

Ljubljana was especially important to me because it was European, a crossroads of cultures, but it was not yet heading in the direction of globalization, a word that didn't exist. It was (is?) human-scale, manageable, medieval and yet also socialist. Perhaps it is a fantasy to link Ljubljana to early Marx; the Titoist third way was a vague mediation. But the fantasy sustained me, especially after Prague fell. Little did I know that Prague, like most of eastern Europe behind the 'Iron Curtain,' would eventually be colonized by western capital and culture; and who would have predicted that the Soviet Union would fissure into ethnic states?

As I said at the outset, autobiography and autobibliography merge. Where one was personally affects and is affected by what one is reading. I was studying the giants of non-positivist European thought, the Germans, French, Hungarians, the Praxis group, as I was coming of age. So place mattered, at least in memory. Reading Kant on the shores of Lake Bohinj produces a different memory than if I had read him in a philosophy class taught by an analytical philosopher in the U.S. It was an omen when I shared a cable car to the top of Mount Vogel with Sartre, Beauvoir and Dedijer. My reading list was standing beside me!

And so my Ljubljana, as I reconstruct it, involved medieval manageability, outdoor cafes where I did my reading, the smoky smell of cevapcici, discussion with my father's Slovene social-science friends, the emerging Titoist take on autogestion, a certain relationship to nature (Bohinj, the Adriatic) which had not yet been paved and malled over, coming of age romantically (of course!), and the house that my parents built on the Croat island of Cres, in a tiny village called Miholascica. As my teens turned into my twenties, and we spent every summer in Ljubljana and other parts of Europe, I felt more at home than I did in the United States, which was surely a factor in our decision to move to Toronto, almost a European city by feel. Wanting to avoid the war in Vietnam was another factor. 
As I recall, there was a direct flight from Toronto to either Ljubljana or Zagreb. I began serious study of European theory while a student in Toronto. My summers in Ljubljana, Zagreb, Beograd, Sarajevo, and on the Adriatic coast began to take on a newfound intellectual meaning as I better understood the Praxis group and their heretical critique of Soviet state socialism from within a different version of socialism. I realized that the Frankfurt School and various existential leftists such as Sartre, Merleau-Ponty and Enzo Paci were tried to rescue the humanism in Marxism ('socialism with a human face) and that Tito's Yugoslavia was a laboratory of this approach to Marx.

This is not to say that workers self-management came out of a theoretical treatise, although theory was definitely involved as humanists behind the so-called Iron Curtain tried to find warrant in Marx for their resistance to the authoritarianism of Stalinism. Ljubljana cannot be reduced to a text; rather, it is a lifeworld (Lebenswelt), as Husserlians call it. And my experience of that everyday life was filtered through prism of my tender years, my North American background, and a good deal of wishful thinking. The cosmopolitan delights of Ljubljana, Paris, Amsterdam were less about theory than about the accretion and momentum of a humane everyday life that has characterized urban Europe since the middle ages. Surely, the intimate, beautiful and manageable built environment of European cities, especially of the scope and scale of Ljubljana, have something to do with this, as does a certain relationship between humanity and nature that is much more common in Europe than in America. It was possible to fantasize that Tivoli Park represented the redemption of nature.

And so my time in Ljubljana was partly about being in Europe and perhaps the very idea of Europe, a topic discussed eloquently by my Slovenian colleague Ales Debeljak. For me, Europe, symbolized by Ljubljana and rural Slovenia, was in part itself and in part not-America, its presence defined by absence. After all, there was little to like about America when I moved to Canada. The authoritarian state of Johnson and Nixon, and later Reagan and Bush Jr., crushed the progressive projects of the black and student movements, even as the war in Vietnam ended simply because it could not be won. (The parallel to Iraq and, I hope, Afghanistan is obvious.)

A Europeanizing reading of Slovenia particularly focuses on the role of intellectual life in the public sphere. When I was last strolling in Paris, Derrida's latest books were on display in non-academic Parisian bookstores. The major chain bookstores in the U.S. have never sold Derrida, let alone Zizek. As I was doing my apprenticeship as a would-be academic, I found in Europe, both western and eastern, an approach to intellectuality defined by engagement. For an apprentice with my particular politics, this engagement was summarized by the eleventh thesis. But one does not need to be a Marxist — and, after all, what does it mean to be a Marxist in the 21st century? — to insert one's intellectual work and life in a public sphere in which people (Europeans!) take ideas seriously. Dominated by materialism and diversion, American public life and popular culture have always been anti-intellectual, embodied by the image of George Babbitt, the protagonist in Sinclair Lewis' novel Babbitt, first published in 1922. That publication year was one year before the publication of Lukacs' History and Class Consciousness, an inaugural work of 'western Marxism' in which he introduces the concept of reification — a deepening of Marx's original alienation. Also in 1923, the Institute for Social Research was established in Germany, the so-called Frankfurt School, which deepened the concept of reification in 'domination' - an ether of everyday unconsciousness closed to thinking the world otherwise, to utopia.

Ljubljana helped me think the world otherwise, as did other parts of Europe. Amsterdam's canals and Prague's castle were not tourist landmarks for me but memory aids that suggested a vital public sphere with a charming cityscape. These examples gave form to worlds thought otherwise, which, for a young American, meant a world outside of suburbs, malls, Henry Ford's factories, office cubicles housed in modernist skyscrapers. Ljubljana represented this other life.

I have not returned to Ljubljana in many years. Everything is bound to be different, or perhaps it never was. Slovenia now stands alone and entered the EU in 2004. I had hoped that Ljubljana would remain the Only City without McDonald's but was disappointed, if unsurprised, that it, too, has been colonized. A fast laptop capitalism, expedited by CNN and FedEx, has destroyed many aspects of indigenous cultural 'difference', much as Marx predicted when he discussed the tendency of the flight of capital. The intellectual and cultural scorched-earth policy of so-called globalization makes me wonder whether 'my' Ljubljana, as I remember it, still exists. Probably, it does and it doesn't. I'd like to return to my former haunts and check this out, but, first, perhaps the passport office could acknowledge my Slovene identity. 
